\title{
Enhancing Kindergarten Student Teachers' Conversation Techniques in the Context of their Teaching Practicum
}

\author{
Elissavet Chlapana* \\ Laboratory Teaching Staff, Department of Preschool Education, University of Crete, Greece
}

*Corresponding Author: Elissavet Chlapana, Laboratory Teaching Staff, Department of Preschool Education, University of Crete, Greece

\begin{abstract}
The aim of the present study was to investigate the conversation techniques that kindergarten student teachers implement in the context of the teaching practicum during their bachelor studies. The sample consisted of 45 undergraduate student teachers attending their teaching practicum in the Department of Preschool Education of the University of Crete. Student teachers were asked to pre-and post-evaluate the frequency with which they implemented essential conversation techniques while teaching in kindergarten classrooms on a five-point Likert scale, and to indicate the factors which may have influenced them in conducting classroom conversations by answering two open ended questions. The results of the present study provided indications of student teachers' preparedness in implementing conversation techniques which can add to children's oral language development and pointed to significant factors which may influence their teaching experiences.
\end{abstract}

Keywords: Conversation Techniques; Undergraduate Student Teachers; Teaching Practicum; Kindergarten

\section{INTRODUCTION}

Early oral language stimuli that children experience in the school environment play a significant role in their language and literacy development [1]. Supporting children's early oral language skills through appropriate practices is considered crucial [2], since they relate significantly with several aspects of their subsequent literacy achievement, such as reading accuracy, fluency and text comprehension [3] [4].

Classroom conversations are considered an essential practice which kindergarten teachers can use to provide children with rich language experiences and models of appropriate language use [5] [2]. Through classroom conversations children learn how the syntactic and semantic aspects of language work, they enrich their vocabularies, and thus they create the foundation for literacy development [6]. Indicatively, research data have shown that preschoolers benefit in oral language skills development from cognitively challenging discussions guided by adults' effective conversations strategies (e.g. use of rare words, linguistic recasts and open-ended questions) [7] [8] [9].

Furthermore, classroom conversations add to a bigger vision which illustrates children's learning and development [6]. Through classroom conversations, children learn to communicate their ideas and thoughts, develop empathy, participate in group meaning making processes and eventually they learn how to become equal members of a learning community where several educational, social and developmental goals are attained [10]. Given the necessity of early classroom language experiences for children's oral language growth, an important question arises on how future kindergarten teachers can be trained and prepared to implement classroom conversation techniques which can contribute to this end.

\subsection{Classroom Conversation Techniques Applied by Teachers in Kindergarten Settings}

Kindergarten teachers need to be aware of effective techniques and guidelines which facilitate conversations, ensure children's equal participation in these and lay the groundwork for their oral language development [11]. At the beginning of the school year, they may need to introduce children to some essential "no interruption" rules, and practice procedures in taking turns [6]. These guidelines provide the interlocutors the opportunity to build their contributions on each other's answers and 
ideas, and eventually construct meaning through cooperative procedures. In this context, teachers' questions become a significant medium which enables the topic of the conversation to unfold, and provides children with the opportunity to adopt patterns of appropriate oral language use. Particularly, teachers need to ask closed and mostly open ended questions to engage children in cognitively challenging conversations. Asking questions of different cognitive demands promotes comprehension of the discussion topic and develops children's higher order thinking [12]. Throughout classroom conversations teachers need also to provide adequate feedback to children's answers, and to expand them by asking follow-up questions or by adding more sophisticated language to children's responses [13]. Furthermore, teachers may encourage children to respond with complete sentences, and gradually transfer to them the responsibility of generating their own questions [13] [14].

In kindergarten settings teachers establish regular and targeted time periods during the daily teaching programme to conduct classroom conversations. On the one hand, playtime and meal or breakfast time are periods when children usually interact in smaller groups, without feeling the pleasure of participating in activities having a well-structured and instructional profile. Teachers can participate in children's spontaneous activities and interactions, and guide their discussions by implementing techniques which foster children's language development. On the other hand, circle-time is the period during which teachers organize activities to attain curricular goals. Among these, reading books is a well-documented activity for its impact on children's language growth. Teachers have the opportunity to engage children in cognitively challenging discussions by encouraging them to analyse the story content and connect it with their personal experiences [12]. Nevertheless, due to the pressure of attaining curriculum goals and classroom management issues many teachers reduce classroom conversations throughout the daily instructional programme [6].

Despite the well-documented contribution of classroom conversations in children's learning and oral language development, there are differences in the amount of time that kindergarten teachers devote to them and the techniques they adopt to conduct classroom conversations. Specifically, Girolametto and Weitzman [15] in their research which was conducted in preschool settings, showed that a few interactive conversation strategies (i.e. using a variety of questions, encouraging turn-taking, expanding, and extending) received low ratings by early childhood educators across the sample study. Furthermore, the results showed that children's age and the interaction context are factors that seem to differentiate educators' language-modelling strategies. Durden and Dangel [16] also found that teachers in general adopted monologic techniques and dominated the classroom conversations by asking predominately low cognitive demand questions. Along the lines of these studies, Chen and de Groot Kim [17] in their research found that the activity context and the time zone of the instructional day affected the interactive conversation techniques preschool teachers used and that, regardless of the context, teachers rarely adopted strategies that involved children in cognitively challenging discussions. In agreement with Chen and de Groot Kim [17], Turnbull et al. [18] investigated the language stimulation techniques that preschool teachers applied while conversing with children in different instructional contexts. One of the most significant results in their study was that only one third of teachers' utterances were related to techniques such as open questions, recasts / expansions, redirects / prompted initiations, and focused contrasts, that effectively support children's language development. The remaining two thirds of teachers' utterances consisted of techniques and language patterns such as directives, closed-ended or rhetorical questions that provided children with less complex language input. Similar to Turnbull et al.'s results, Dickinson, Darrow, and Tinubu [19] in their study showed that all teachers applied some strategies likely to enhance children's language growth, but the frequency was low. Overall, the research results [15] [16] [17] [18] [19] showed the relatively limited use of effective conversation techniques by early childhood teachers. They also highlighted the need for professional development in practices which would guide them in adopting conversation strategies that foster children's language development. With regard to this parameter, research studies showed that teachers' in-service training and professional development can contribute to improving the conversation techniques they apply in the school context [20] [21] [22] [23]. Given the relatively insufficient use of effective classroom conversation techniques by early childhood teachers and the necessity of in-service training, a significant question arises about the degree to which their initial and basic professional training during their undergraduate studies contributes to their preparedness in implementing effective conversation practices in classroom. 


\subsection{Teaching Practicum as a Context for Training Student Teachers in Classroom Conversation Techniques And Literacy Instruction}

Student teachers' participation in teaching practicum or teaching field experiences constitutes an integral part of their undergraduate studies [24] [25]. In general, the aim of the practicum in all university pedagogical departments is common, and that is to connect student teachers with educational procedure and to train them in classroom teaching and management [26]. Student teachers seem to recognize the benefits of the practicum with regard to the knowledge, skill, flexibility and efficacy that are required in teaching [27].

Practicum courses can become an appropriate context for student teachers to be trained by their tutors in implementing research-based practices which can contribute to children's language and literacy development [28]. While there are few studies addressing issues related to in-service teachers' training in conversation strategies, there are fewer studies investigating how university courses can help student or pre-service teachers prepare to implement effective literacy practices [10] and even less empirical evidence on the improvement of student teachers' conversation skills during their field teaching experiences. For example there are studies which examined issues regarding: (a) pre-service and students teachers' perceptions and knowledge of children's language skills, such as phonological awareness [29], literacy [30] [31] [32] and writing instruction [33], and (b) the impact of different tutoring programs on preparing student teachers in reading instruction [28]. With regard to the improvement of the conversation strategies of student teachers, the only available data were obtained by Carr [10]. In her research Carr reported that early childhood student teachers on the practicum that took place at her university recorded and analysed their conversations with young children. Student teachers were surprised by the number of closed questions they used. Gradually they became more experienced in conversing with children in different contexts and listening to their responses carefully.

\subsection{The Study}

Taking into consideration the significance of teachers' effective conversation techniques for young children's oral language development and the contribution of the teaching practicum in student teachers' professional training, the present study aims to describe: (i) the conversation techniques that kindergarten student teachers apply while teaching in kindergarten classrooms during their practicum, (ii) the key factors that helped them conduct classroom conversations and (iii) the difficulties they encountered that hindered the conversations they conducted with children while teaching in the classroom.

\section{METHODS}

\subsection{Participants}

Forty five (45) student teachers, 43 females and 2 males, of the Department of Preschool Education of the University of Crete participated in the study. Student teachers were in the third of the four years of their undergraduate studies. Student teachers at the time of this study were attending level II of their practicum, which takes place over two academic semesters (winter and spring semester). The practicum is held in public kindergarten schools located in Rethymno, Crete.

\subsection{Student Teachers' Training in Teaching and in Conversation Techniques in the Context of the Teaching Practicum Level II}

The general aim of practicum level II in the Department of Preschool Education in the University of Crete is familiarizing student teachers with the practical aspect of their studies (that is, the teaching process) and implementing the particular principles, theories and methodologies proposed by contemporary developments in teaching. The special goals of practicum level $\mathrm{II}^{1}$ were training student teachers in the kindergarten curriculum, questioning and conversation techniques, reading aloud practices and cross-curricular activities which are organized based on a cross-thematic approach. Student teachers were trained in the above topics and prepared in the daily teaching programmes they

\footnotetext{
${ }^{1}$ Third-year student teachers are divided into three groups. Each group is assigned to a different member of the faculty teaching staff who is in charge of the student teachers' training and has the flexibility to design the special goals and the content of the programme.
} 
were going to implement in university laboratory lessons conducted by their tutor (author). Student teachers were in charge of teaching for half or the entire daily teaching schedule of a preschool class.

For the winter semester the content of student teachers' daily teaching programmes was organized as follows. At the beginning of the daily teaching schedule student teachers read a carefully selected storybook to children. Reading aloud served as a context for student teachers to conduct a guided conversation with children so as to analyse the story content and specify topics which emerged from the story plot. The topics served as a link between the story and the kindergarten curriculum, and were processed with cross-curricular activities conducted during the rest of the daily teaching programme.

During the spring semester student teachers were instructed to organize and implement daily teaching programmes which were based on the development of thematic units related to topics derived from the natural and social environment. The instructional activities designed for each thematic unit extended over two days. Particularly, each thematic unit was developed as follows. At the beginning of the first day of the teaching programme the student teachers conducted a playful activity to introduce children to the topic of each thematic unit. Then they read a relevant informational text to the children and discussed it with them. Having read the text, the student teachers developed each thematic unit during the first and the second day of instruction with cross-curricular activities derived from the kindergarten curriculum.

Throughout the practicum level II, student teachers were instructed by the course tutor to follow specific guidelines to conduct conversations with children on the content of the activities anticipated by the daily teaching schedule. The basic guidelines were the following:

- Ensure children's active and equal participation in the classroom conversation. Encourage diffident and hesitant children to become involved in the topic of conversation.

- Relate the topic of conversation to children's personal experiences.

- Expand children's answers with more information and more sophisticated vocabulary.

- Provide adequate feedback to children's responses.

- Enhance children's cognitive involvement in the conversation. Ask closed and open ended questions to enhance children's oral language skills.

- Ensure that conversation rules are followed. These rules pertain to principles of taking turns in a conversation.

- "The magic wait time". Provide the necessary time for all the children to form an answer to the question you asked.

\subsection{Measures and Procedure}

Student teachers self-evaluated their conversation techniques through an eighteen-item check list which was designed by Miller [6]. The check list evaluated conversation techniques which are considered appropriate for fostering children's oral language development. Student teachers were asked to estimate the frequency with which they applied each of the assessed conversation techniques on a five-point Likert scale ( 1 = very rarely, $2=$ rarely, $3=$ sometimes, 4 =often, $5=$ very frequently $)$. Miller's check list items were translated into Greek by the author and retranslated by an English language specialist for translation accuracy. The check list was then administered to twenty fourthyear undergraduate students of the Department of Preschool Education of the University of Crete in order to evaluate the linguistic and conceptual clarity of the check list. A few corrections and modifications were made to some items so as to make them absolutely comprehensible and representative of conversation techniques applied in Greek kindergarten classrooms.

Student teachers answered the check list at the end of the winter semester and then answered it again at the end of the spring semester. This second measure served as a posttest which aimed to evaluate the consistency or change in student teachers' self-evaluations. Cronbach's a reliability coefficient was 0.65 for the pretest and 0.78 for posttest. These results indicate that the reliability coefficient was satisfactory for the purpose of the present study. 
Furthermore, at the second measurement student teachers were asked to answer two open ended questions in order to indicate: (a) what they considered the key factors that facilitated the classroom conversations and (b) the key parameters that hindered the discussions they conducted with children in the classroom. Student teachers' answers to the two open ended questions were recorded, analysed by the technique of content analysis and consolidated into categories based on their common characteristics. Particularly, for each question an initial analysis code was composed based on a restricted number of answers. During the data analysis, the code analysis for each question was enriched and modified in order for more accurate and distinct categories to be defined.

Student teachers consented to fill out the check list and answer to the open-ended questions. According to their comments, they found this procedure helpful in reflecting on the practices they implemented throughout their practicum.

\section{Results}

The first goal of the present study was to examine the conversation techniques applied by student teachers while teaching in kindergarten school settings throughout level II of their teaching practicum. According to the results (Table 1), student teachers' self-ratings on the majority of the reported conversation techniques remained consistent throughout level II of their practicum. Student teachers reported that they rarely applied inappropriate techniques (see indicatively Q3, Q7, Q9, Q11 on Table 1). On the contrary, and based on their self-assessments, student teachers quite often reported to have implemented techniques which promote classroom conversation, facilitate teacher-children individual interactions and help children improve their oral language skills (see indicatively Q2, Q12, Q14, Q15, Q18 on Table 1). Furthermore, results showed that to a statistically significant degree student teachers reported to have increased the frequency with which they: a) conducted conversations that help children to handle puzzles or problem solving (Q4), b) added words to the conversation they conducted in order to expand or elaborate on what children said or asked (Q6), c) used words to make their expectations clear and redirect children to more acceptable activities (Q8) and d) ensured equal involvement in the classroom conversation (Q15). On the contrary, to a statistically significant degree the student teachers reported to have decreased the frequency with which they dominated the classroom conversation by doing most of the talking while conversing with children (Q13).

Table1. Means $(M)$ and standard deviations (SD) on student teachers' self-ratings on the conversation techniques and paired sample t test results on student teachers' pre and post assessments

\begin{tabular}{|c|c|c|c|c|}
\hline & Check list items & $M$ & $S D$ & Paired sample $t$ test \\
\hline \multirow[t]{3}{*}{1.} & Most of my questions can be answered with "yes" or "no". & & & \\
\hline & Pretest & 2.69 & 0.82 & \multirow[t]{2}{*}{$\mathrm{t}(44)=0.36$} \\
\hline & Posttest & 2.64 & 0.71 & \\
\hline \multirow[t]{3}{*}{2.} & I ask open type questions. & & & \\
\hline & Pretest & 3.69 & 0.79 & \multirow[t]{2}{*}{$\mathrm{t}(44)=-1.23$} \\
\hline & Posttest & 3.84 & 0.67 & \\
\hline \multirow[t]{3}{*}{3.} & I raise my voice to get children's attention. & & & \\
\hline & Pretest & 1.91 & 1.10 & \multirow{2}{*}{$t(44)=0.21$} \\
\hline & Posttest & 2.09 & 1.06 & \\
\hline \multirow[t]{3}{*}{4.} & $\begin{array}{l}\text { My conversations aim to help children to discover how to } \\
\text { solve puzzles or problems. }\end{array}$ & & & \\
\hline & Pretest & 2.80 & 1.06 & \multirow[t]{2}{*}{$* t(44)=-2.53$} \\
\hline & Posttest & 3.22 & 0.95 & \\
\hline \multirow[t]{3}{*}{5.} & $\begin{array}{l}\text { My answers to children-initiated questions are short and } \\
\text { direct. }\end{array}$ & & & \\
\hline & Pretest & 2.89 & 0.89 & \multirow[t]{2}{*}{$\mathrm{t}(43)=1.21$} \\
\hline & Posttest & 2.64 & 1.03 & \\
\hline \multirow[t]{3}{*}{6.} & $\begin{array}{l}\text { In a conversation I expand children's questions and responses } \\
\text { or elaborate them by adding words. }\end{array}$ & & & \\
\hline & Pretest & 3.38 & 0.83 & \multirow[t]{2}{*}{$* t(44)=-2.63$} \\
\hline & Posttest & 3.69 & 0.76 & \\
\hline \multirow[t]{3}{*}{7.} & I use one or three word commands when addressing children. & & & \\
\hline & Pretest & 2.47 & 1.25 & \multirow[t]{2}{*}{$\mathrm{t}(44)=0.00$} \\
\hline & Posttest & 2.47 & 0.92 & \\
\hline
\end{tabular}




\begin{tabular}{|c|c|c|c|c|}
\hline 8. & $\begin{array}{l}\text { I use words rather than intense moves or gestures to express } \\
\text { my expectations and redirect children to more acceptable } \\
\text { activities. }\end{array}$ & & & \\
\hline & Pretest & 3.42 & 1.06 & \multirow[t]{2}{*}{$*_{t}(44)=-2.53$} \\
\hline & Posttest & 3.85 & 1.07 & \\
\hline \multirow[t]{3}{*}{9.} & $\begin{array}{l}\text { I talk to children using short and simple sentences. I use baby } \\
\text { talk. }\end{array}$ & & & \\
\hline & Pretest & 2.09 & 0.93 & \multirow[t]{2}{*}{$\mathrm{t}(44)=1.35$} \\
\hline & Posttest & 1.87 & 0.97 & \\
\hline \multirow[t]{3}{*}{10.} & $\begin{array}{l}\text { I use long, complex sentences with varied vocabulary when I } \\
\text { talk to the children. }\end{array}$ & & & \\
\hline & Pretest & 2.62 & 0.94 & \multirow{2}{*}{$\mathrm{t}(44)=-0.24$} \\
\hline & Posttest & 2.67 & 1.09 & \\
\hline \multirow[t]{3}{*}{11.} & $\begin{array}{l}\text { I tend to stand over or away from (usually at the front of the } \\
\text { classroom) children when I talk to them. }\end{array}$ & & & \\
\hline & Pretest & 2.62 & 1.32 & \multirow[t]{2}{*}{$\mathrm{t}(44)=1.82$} \\
\hline & Posttest & 2.13 & 1.37 & \\
\hline \multirow[t]{3}{*}{12.} & $\begin{array}{l}\text { I place myself at a child's level when I speak to him/her } \\
\text { individually. }\end{array}$ & & & \\
\hline & Pretest & 3.93 & 1.25 & \multirow{2}{*}{$\mathrm{t}(44)=-0.47$} \\
\hline & Posttest & 4.02 & 1.18 & \\
\hline \multirow[t]{3}{*}{13.} & $\begin{array}{l}\text { I do most of the talking when conducting a conversation with } \\
\text { the children. }\end{array}$ & & & \\
\hline & Pretest & 3.18 & 0.70 & \multirow[t]{2}{*}{$* t(42)=2.55$} \\
\hline & Posttest & 2.86 & 0.83 & \\
\hline \multirow[t]{3}{*}{14.} & $\begin{array}{l}\text { I look at the children's faces and listen to them carefully when } \\
\text { they are talking. }\end{array}$ & & & \\
\hline & Pretest & 4.66 & 0.81 & \multirow{2}{*}{$\mathrm{t}(43)=0.62$} \\
\hline & Posttest & 4.72 & 0.50 & \\
\hline \multirow[t]{3}{*}{15.} & $\begin{array}{l}\text { All participants contribute equally to the conversation (e.g. } \\
\text { turn-taking rules are followed). }\end{array}$ & & & \\
\hline & Pretest & 4.06 & 0.91 & \multirow[t]{2}{*}{$* t(43)=-2.05$} \\
\hline & Posttest & 4.37 & 0.65 & \\
\hline \multirow[t]{3}{*}{16.} & Most of what I say to children aims to correct or direct them. & & & \\
\hline & Pretest & 2.86 & 0.88 & \multirow[t]{2}{*}{$\mathrm{t}(43)=1.09$} \\
\hline & Posttest & 2.71 & 1 & \\
\hline \multirow[t]{3}{*}{17.} & $\begin{array}{l}\text { Most of my conversations focus on mistakes children have } \\
\text { made or problems they have caused. }\end{array}$ & & & \\
\hline & Pretest & 1.96 & 0.73 & \multirow[t]{2}{*}{$\mathrm{t}(44)=1.31$} \\
\hline & Posttest & 1.80 & 0.69 & \\
\hline \multirow[t]{3}{*}{18.} & I talk to children about topics they are interested in. & & & \\
\hline & Pretest & 3.89 & 0.86 & \multirow{2}{*}{$t(44)=-0.17$} \\
\hline & Posttest & 3.91 & 0.70 & \\
\hline
\end{tabular}

Note. a. $1=$ very rarely, $2=$ rarely, $3=$ sometimes, $4=$ often, $5=$ very frequently

b. $* \mathrm{p}<0.05$

Furthermore, student teachers were asked to identify the key factors which helped them conduct the classroom conversations throughout the level II of their practicum. According to their answers (Table 2), the most frequently identified factors which facilitated classroom conversations were student teachers' familiarity with the children, the teaching experience they acquired throughout the two semesters of their practicum, as well as the relevant laboratory lessons that were held in the university. Fewer student teachers identified: a) appropriate preparation of their daily teaching programme, b) the degree to which children were interested in the conversation topic and were given time and space to discuss it in their terms and c) their training in the questioning techniques as factors that helped them conduct the classroom conversations. Even fewer identified factors more directly related to children's cognitive and language level or to the daily teaching program preparation such as the materials available on the course electronic website and the guidelines provided by the official kindergarten curriculum. 

Practicum

Table2. Frequency $(f)$ and relative frequency (\%) of the key factors that student teachers consider to have facilitated the classroom conversations

\begin{tabular}{|c|c|c|}
\hline & $\mathrm{f}$ & $\%$ \\
\hline Kindergarten curriculum & 1 & 2.2 \\
\hline Conversation time during the daily programme & 3 & 6.5 \\
\hline Materials available on the course electronic website & 4 & 8.7 \\
\hline Motivating children in predicting conversation topic & 4 & 8.7 \\
\hline Children's language and cognitive maturity & 4 & 8.7 \\
\hline Conversation topic & 7 & 15.2 \\
\hline Training in questioning techniques & 7 & 15.2 \\
\hline Giving time and priority to children for conversation topic elaboration & 7 & 15.2 \\
\hline Appropriate organisation of teaching programme & 8 & 17.4 \\
\hline University laboratory lessons & 14 & 30.4 \\
\hline Previous teaching experience & 16 & 34.8 \\
\hline Familiarity with children & 17 & 37 \\
\hline
\end{tabular}

Supplementary to these results, student teachers were asked to identify the key factors that hindered their attempts to conduct conversations with children. According to the results presented in Table 3 , the student teachers reported several factors which relate mainly to classroom management issues and to the teaching process parameters. Specifically, classroom noise and more confident children's domination over the more hesitant ones were identified as the most frequent factors which hindered student teachers from conducting smooth classroom conversations. Furthermore, several other personal and instructional factors were reported such as student teachers' teaching anxiety and the lack of teaching experience, children's low interest in the conversation topic and children's tiredness because of the implemented instructional activities. Additionally, cooperating teachers' involvement in the activities designed and implemented by the student teachers constituted a parameter that interfered in the classroom conversations.

Table3. Frequency $(f)$ and relative frequency $(\%)$ of the key factors that student teachers consider to have hindered classroom conversations

\begin{tabular}{|l|l|l|}
\hline & f & $\%$ \\
\hline Cooperating teachers' different instructional approach & 1 & 2.2 \\
\hline Inappropriate instructional time management & 3 & 6.5 \\
\hline Special needs children & 2 & 4.3 \\
\hline Student teachers' authority questioned by children & 5 & 10.9 \\
\hline Lack of teaching experience & 5 & 10.9 \\
\hline Children's tiredness & 6 & 13 \\
\hline Cooperating teachers' interference during the teaching activities development & 7 & 15.2 \\
\hline Teaching anxiety & 9 & 19.6 \\
\hline Lack of interest in the topic of conversation & 10 & 21.7 \\
\hline A few children's dominating the conversation & 14 & 30.4 \\
\hline Classroom noise & 27 & 58.7 \\
\hline
\end{tabular}

\section{DISCUSSION}

The aim of the present study was to describe the conversation techniques student teachers reported to have used while teaching in kindergarten classrooms as part of their teaching practicum during their bachelor studies. The results extracted from student teachers' self-assessments provide indications that the professional training received in the context of their teaching practicum may contribute to their flexibility and readiness to follow guidelines and apply techniques which enable classroom conversations to be conducted.

The content of the conversation topic constituted the first parameter when analysing the quality of discussions taking place in school contexts. According to the results of the present study, during their practicum student teachers reported to have centred classroom conversations mostly around topics that children were interested in (Q18). Specifically, children's interest in the conversation topic seemed to be a priority for them and also a significant factor which facilitated the conversation or decreased children's participation in it. Choosing topics which are close to children's interests provides the initial context to engage them in a meaningful talk and to motivate them to express their 
feelings and personal experiences freely. This may become an opportunity for teachers to apply language modelling techniques, such as the use of appropriate vocabulary, which can enhance children's language development [5].

While student teachers reported that they rarely centred conversations around mistakes children made or problems they caused (Q17), they frequently reported that they conducted conversations which focused on helping children discover how to solve puzzles or problems (Q4), and the fact that they used words to make their expectations clear and redirect children to more acceptable activities (Q8).These results provide indications that student teachers did not want a superficial picture of the problems that emerged in the classroom but intended to use language and conversations to confront possible difficulties or problems related to children's activities. Problem-solving conversations can be used as a medium which can influence children's behaviour and development because it provides them with the opportunity to reflect on their actions and choices and learn from their experiences [34]. Relevant to the above results and along the lines of the study by Chen and de Groot Kim [17], student teachers in the present study reported that they talked to children face to face very frequently, placing themselves at the child's level (Q12, Q14). This is a significant a child-centred strategy which ensures proximity among interlocutors. In this context children perceive their teacher as an equal member of their group who listens carefully to their responses and pays attention to their comments and worries.

Of special interest were the results of student teachers' self-assessments showing that they significantly increased the frequency with which they reported to have applied techniques of essential conversation rules which ensure equality among those holding a conversation (Q15). Unlike the study of Girolametto and Weitzman [20], which was conducted with in-service early childhood teachers, student teachers in the present study seemed to acknowledge the necessity of enabling interlocutors to participate in a conversation on equal terms and thus help them benefit in comprehending the topic and learn from each other's verbal contributions [6].

In accordance with results presented above are results which showed that student teachers significantly decreased the frequency with which they did most of the talking when conducting a conversation with the children (Q13). In contract to the results of the study by Durden and Dangel [16] who found that the teachers in general adopt monologic techniques, student teachers seemed to recognize that the verbal interaction among interlocutors should not be unidirectional, moving from the teacher to the children. Teachers should promote interaction between children and gradually transfer to them the responsibility of generating their own questions and comments [13] [14].

Positive were also the results which showed that open ended questions (Q2) were more frequently used than closed type questions (Q1). In their self-assessments student teachers, unlike the results presented in the study of Durden and Dangel [16], seemed to recognize the need for balance in asking questions of different cognitive demand and the value of open ended questions for children's language growth and for the development of their critical thinking [12] [13].

Relevant to reported frequent use of open ended questions were the results which showed that student teachers significantly increased the frequency with which they added words to the conversation they conducted in order to expand or elaborate on what children said or asked (Q6). This is a significant language modelling strategy which teachers can use to add more sophisticated language to children's responses [13]. Furthermore, student teachers assigned low scores to techniques such as short and simple sentences, corrections and/or directions, and baby talk (Q9, Q16), which are not considered effective for children's language development. These data provide some indications that they created a conversation context in which young children received advanced language input and experienced language patterns which can add significantly to their language growth and literacy development. In general, the results of the present study seem to deviate to some degree from the results of related studies (e.g. [15] [16] [17] [19] [18]) which were conducted with early childhood teachers. The comparison between student teachers and in-service teaches gives rise to significant questions regarding the degree to which future teachers maintain the teaching practices they adopted during their initial professional training and the factors which may cause any alterations in these. Are the lack of subsequent professional development, the pressure of curriculum implementation and children's diverse individual and social characteristics responsible for alterations made in future teachers' conversation practices? These are interesting questions for future research to investigate. 
Additionally, student teachers in the present study were asked to indicate the factors which may facilitate or hinder classroom conversations. Their familiarity with the children and the teaching experience obtained during their teaching practicum were the most frequently reported factors which gave them self-confidence in conducting classroom conversations. Previous teaching experience is a parameter that student teachers often refer to [35], and it seems that is apparent in all the instructional activities that they are asked to implement during their teaching practicum. Furthermore, based on student teachers' self-reports, the university laboratory lessons were another factor which may have contributed to their preparedness in conducting classroom conversations. Specifically, student teachers were trained in implementing effective story and informational text reading practices and organizing the cross curricular activities based on the texts. Taking into consideration the study of $\mathrm{Al}$ Otaiba et al. [28], tutoring programmes aiming to instruct student teachers in evidence-based book reading methods can enhance, to some degree, their knowledge and skill in implementing practices contributing to young children's future language and literacy achievement. Student teachers were also asked to identify the key parameters that hindered classroom conversation. With regard to this question, in line with previous research [35], classroom management issues seemed to dominate student teachers' concerns about classroom conversations. Besides that, anxiety related to the teaching process, as well as the interference of the cooperating teachers in the activities that student teachers implemented in the classrooms, were parameters that affected their attempts to converse with children. Cooperating teachers' interference, according to relevant research [30] [33], may be due to the different teaching approaches they had adopted and established throughout their professional careers. This may cause a conflict in student teachers' teaching choices and be responsible for any modifications in the teaching programme they implement.

Overall, the results indicate that student teachers' professional training during their teaching practicum is a multidimensional procedure which is influenced by the goals and the organization of the tutoring programme they attend, their personal traits and classroom parameters such as classroom management issues and cooperating teachers' teaching practices. Of course, in the present study there are significant limitations that should be mentioned. The results of the present study should be interpreted cautiously given the small sample size, the absence of a control group where student teachers attended a different tutoring programme, and the fact that the results were obtained exclusively by student teachers' self-assessments. Nevertheless, the results provide indications that the organization of student teachers' teaching practicum, based on a tutoring programme which promotes oral language experiences in the school environment, may lay the ground for preparing them in implementing effective conversation practices which can contribute to young children's oral language development.

\section{IMPLICATIONS}

The results of the present study provided indications that student teachers' teaching practicum during their bachelor studies could be used as a context to train them in practices which are effective for young children's oral language skills development. Training student teachers to conduct guided conversations embedded in read alouds and cross-curricular activities is significant for their initial professional development in language and literacy instruction. Choosing topics which are close to children's interests, encouraging cognitively advanced conversations and ensuring interaction and interlocutors' equal contribution in the conversation topic are some of the basic guidelines which future teachers should follow. These guidelines can enhance future teachers' conversation skills and allow classroom conversations to become an effective context for fostering young children's oral language development.

\section{REFERENCES}

[1] Dickinson, D. K., \& Porche, M. V. (2011). Relation between language experiences in preschool classrooms and children's kindergarten and fourth-grade language and reading abilities. Child Development, 82(3), 870-886. doi: 10.1111/j.1467-8624.2011.01576.x.

[2] Whorrall, J., \& Cabell, S. Q. (2016). Supporting children's oral language development in the preschool classroom. Early Childhood Education Journal, 44, 335-341. doi: 10.1007/s10643-015-0719-0.

[3] Kendeou, P., van den Broek,P., White, M. J., \& Lynch, J. S. (2009). Predicting reading comprehension in early elementary school: The independent contributions of oral Language and decoding skills. Journal of Educational Psychology, 101(4), 765-778. doi: 10.1037/a0015956. 
[4] Papadimitriou, A. M., \& Vlachos. F. M. (2014). Which specific skills developing during preschool years predict the reading performance in the first and second grade of primary school? Early Child Development and Care, 184(11), 1706-1722.doi:10.1080/03004430.2013.875542.

[5] Bond, M. A., \& Wasik, B. A. (2009). Conversation stations: Promoting language development in young children. Early Childhood Education Journal, 36(6), 467-473.

[6] Miller, C. P. (2010). Before they read: teaching language and literacy development through conversations, interactive read-alouds, and listening games. Gainesville, FL: Maupin House Publishing.

[7] MacLean, C. (2007). The effect of cognitively challenging conversation on oral language development in low-income children. Retrieved from: http://juro.uga.edu/2007/2007papers/christophermaclean.pdf

[8] MacLean, C. (2008). Language expansion and oral communication skills in preschool children. Retrieved from: https://getd.libs.uga.edu/pdfs/maclean_christopher_200805_ma.pdf

[9] Ruston, H. P., \& Schwanenflugel, P. J. (2010). Effects of a conversation intervention on the expressive vocabulary development of prekindergarten children. Language, Speech, and Hearing Services in Schools, 41, 303-313.

[10] Carr, M. (2011). Young children reflecting on their learning: teachers' conversation strategies. Early Years, 31(3), 257-270.

[11] Curenton, S. M., \& Zucker. T. (2013). Instructional conversations in early childhood classrooms: Policy suggestions for curriculum standards and professional development. Creative Education, 4(7), 60-68.

[12] Massey, S. L. (2004). Teacher-child conversation in the preschool classroom. Early Childhood Education Journal, 31(4), 227-231.

[13] Wasik, B. A., \& Hindman, A. H. (2013). Realizing the promise of open-ended questions. The Reading Teacher, 67(4), 302-311.

[14] Becker, R. R. (2000). The critical role of students' questions in literacy development. The Educational Forum, 64(3), 261-271.

[15] Girolametto, L., \& Weitzman, E. (2002). Responsiveness of child care providers in interactions with toddlers and preschoolers. Language, Speech, and Hearing Services in Schools, 33, 268-281. doi:10.1044/0161-1461(2002/022).

[16] Durden, T., \& Dangel, J. R. (2008). Teacher-involved conversations with young children during small group activity. Early Years, 28(3), 251-266.

[17] Chen, J. H., \& de Groot Kim, S. (2014). The quality of teachers' interactive conversations with preschool children from low-income families during small-group and large-group activities. Early Years: An International Research Journal, 34(3), 271-288.

[18] Turnbull, K. R., Beckman Anthony, A., Justice, L., \& Bowles, R. (2009). Preschoolers' exposure to language stimulation in classrooms serving at-risk children: The Contribution of group size and activity context. Early Education and Development, 20(1), 53-79.

[19] Dickinson, D. K., Darrow, C. L., \& Tinubu, T. A. (2008). Patterns of teacher-child conversations in Head Start classrooms: Implications for an empirically grounded approach to professional development. Early Education and Development, 19(3), 396-429.

[20] Girolametto, L., \& Weitzman, E. (2007). Promoting peer interaction skills: Professional development for early childhood educators and preschool teachers. Topics in Language Disorders, 27(2), 93-110.

[21] Girolametto, L., Weitzman, E., \& Greenberg, J. (2003). Training day care staff to facilitate children's language. American Journal of Speech-Language Pathology, 12, 299-311. doi:10.1044/10580360(2003/076).

[22] Milburn, T. F., Girolametto, L., Weitzman E., \& Greenberg, J. (2014). Enhancing preschool educators' ability to facilitate conversations during shared book reading. Journal of Early Childhood Literacy, 14(1), $105-140$.

[23] Wasik, B. A., Bond, M. A., \& Hindman, A. (2006). The effects of a language and literacy intervention on Head Start children and teachers. Journal of Educational Psychology, 98(1), 63-74.

[24] Anderson, L. M., \& Stillman. J. A. (2013). Student teaching's contribution to preservice teacher development: A review of research focused on the preparation of teachers for urban and high-needs contexts. Review of Educational Research, 83(1), 3-69.

[25] Saracho, O. N., \& Spodek, B. (2007). Early childhood teachers' preparation and the quality of program outcomes. Early Child Development and Care, 177(1), 71-91.

[26] Darling-Hammond, L. (2010). Constructing 21st-century teacher education. In V. Hill-Jackson \& C. W. Lewis (eds.), Transforming teacher education. What went wrong with teacher training and how we can fix it (249-252). Sterling, VA: Stylus Publishing, LLC. 
[27] Caires, S., L. Almeida, \& Vieira, D. (2012). Becoming a teacher: student teachers' experiences and perceptions about teaching practice. European Journal of Teacher Education, 35(2), 163-178.

[28] Al Otaiba, S. A., Lake, V. E., Greulich, L., Folsom, J. S., \& Guidry, L. (2012). Preparing beginning reading teachers: An experimental comparison of initial early literacy field experiences. Reading and Writing, 25(1), 109-129. doi: 10.1007/s11145-010-9250-2.

[29] Martinussen, R., Ferrari, J., Aitken, M., \& Willows, D. (2015). Pre-service teachers' knowledge of phonemic awareness: relationship to perceived knowledge, self-efficacy beliefs, and exposure to a multimedia-enhanced lecture. Annals of Dyslexia, 65(3), 142 -158.

[30] Kunz, K. (2015). Not just another course: Exploring exemplary literacy practices in a study group with student teachers. Unpublished doctoral dissertation, The State University of New Jersey.

[31] Mather, N., Bos,C., \& Babur, N.(2001). Perceptions and knowledge of preservice and in service teachers about early literacy instruction. Journal of Learning Disabilities, 34(5), 472-482.

[32] Williams, A. (2013). Effects of intervention on undergraduate pre-service teachers in literacy education. Unpublished doctoral dissertation, Texas A \& M University - Corpus Christi.

[33] Ihmeideh, F., Al-Basheer, A., \& Al-Momani, I. (2008). Jordanian student teachers' perceptions of teaching writing in kindergartens during their field training experience. European Journal of Teacher Education, 31(4), 403-417. doi:10.1080/02619760802420800.

[34] Dwairy, M. (2005). Using problem-solving conversation with children. Intervention in School and Clinic, 40(4), 144-150.

[35] Poulou, M. (2007). Student-teachers' concerns about teaching practice. European Journal of Teacher Education, 30(1), 91-110.

\section{AUTHORS' BIOGRAPHY}

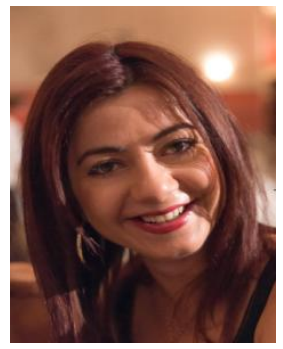

Elissavet Chlapana, received Ph.D. in Sciences of Education with specialization in Preschool Education Teaching Methodology and MEd in Preschool Pedagogics from University of Crete. In my dissertation I studied issues related to immigrant kindergarten children's second language vocabulary development through literacy practices. Since 2014, I am working as Laboratory Teaching Staff in the Department of Preschool Education of University of Crete. My research focuses on Preschool Education Teaching Methodology and teaching practices for the development of young children's literacy skills, especially in the domains of oral language, vocabulary, text comprehension and story structure knowledge.

Citation: Elissavet Chlapana. “Enhancing Kindergarten Student Teachers' Conversation Techniques in the Context of their Teaching Practicum". International Journal of Humanities Social Sciences and Education (IJHSSE), vol 5, no. 4, 2018, pp. 1-11 doi: http://dx.doi.org/10.20431/2349-0381.0501001.

Copyright: (C) 2018 Authors. This is an open-access article distributed under the terms of the Creative Commons Attribution License, which permits unrestricted use, distribution, and reproduction in any medium, provided the original author and source are credited. 